\title{
Deep-sea adaptation of the epipelagic chaetognath Sagitta elegans in the Japan Sea
}

\author{
Makoto Terazaki \\ Ocean Research Institute, University of Tokyo, 1-15-1 Minamidai, Nakano-ku, Tokyo 164, Japan
}

\begin{abstract}
The Japan Sea is a semi-isolated marginal sea connected to the Pacific by 4 shallow straits. The only important current flowing into this sea today is the warm Tsushima Current entering through the southern strait. Between 20000 and 10000 yr ago, the cold Oyashio Current flowed into the Japan Sea through its northern straits. The epipelagic chaetognath Sagitta elegans was introduced into this sea during this period, but shallow straits prevented the invasion of deep-sea chaetognaths. All other chaetognath species were introduced into this sea by the warm current within the last $10000 \mathrm{yr}$ and inhabit the epipelagic layer. $S$. elegans is distributed as deep as $1000 \mathrm{~m}$ or more, but feeding activity is low in the deep water. The size and number of grasping spines and teeth of the Japan Sea specimens are larger than those from the Pacific. They have also developed intestinal tissue containing oil droplets, like meso- and bathypelagic species. These features are adaptations to the deep-water environment. The vertical dispersal of $S$, elegans is facilitated by the absence of competitors such as Eukrohnia hamata, E. fowleri and S. macrocephala in this marginal sea.
\end{abstract}

\section{INTRODUCTION}

The Japan Sea is a semi-isolated marginal sea with an average depth of $1350 \mathrm{~m}$ and a maximum water depth of approximately $3700 \mathrm{~m}$ in the northern basin. It is connected with the Sea of Okhotsk, the North Pacific, and the East China Sea through 4 shallow straits: Tatarskiy Strait $(15 \mathrm{~m})$, Soya Strait $(55 \mathrm{~m})$, Tsugaru Strait $(130 \mathrm{~m})$, and Tsushima Strait $(130 \mathrm{~m})$. The only important current flowing into the Japan Sea today is the Tsushima Current, a branch of the warm Kuroshio Current, which enters through the Tsushima Strait between Kyushu and Korea and flows out to the Pacific through the Tsugaru Strait and Soya Strait. Water of the Japan Sea proper occupies the deeper parts of the Japan Sea (below $200 \mathrm{~m}$ ) and is characterized by low temperature $\left(0.1\right.$ to $\left.0.3^{\circ} \mathrm{C}\right)$, low salinity (34.0 to $34.1 \mathrm{PSU}$ ) and high dissolved oxygen content (5 to $6 \mathrm{ml} \mathrm{l}^{-1}$ ) (Zenkevitch 1963). It has long been known that both boreal and subtropical faunas exist together in the greater part of the Japan Sea (Nishimura 1965).

Sixteen species of pelagic chaetognaths in 3 genera have been reported from the Japan Sea (Kitou 1974).
Sagitta elegans is a relatively large boreal chaetognath which is most abundant in neritic waters. Its usual southernmost limit of occurrence is the lower boundary of the Pacific Subarctic Water (Bieri 1959, Alvariño 1965). S. elegans have been collected in water of the Japan Sea proper and show a remarkable diurnal vertical migration (Terazaki \& Marumo 1979). Fifteen species of temperate and subtropical chaetognaths are carried into the Japan Sea by the Tsushima Current (Kitou 1974).

The present study aimed to clarify whether Sagitta elegans inhabits the meso- and bathypelagic layer of the Japan Sea. For this purpose, studies on distribution pattern, feeding habits, chemical components, and morphology have been performed since 1970 .

\section{METHODS}

Zooplankton was collected by ORI-100 net (Omori 1965) and MTD net (Motoda 1971) on 5 cruises aboard the RV 'Hakuhó Maru' and RV 'Tansei Maru' of the Ocean Research Institute, University of Tokyo, during 1970, 1984, 1985, 1987 and 1989 (Fig. 1). In August 


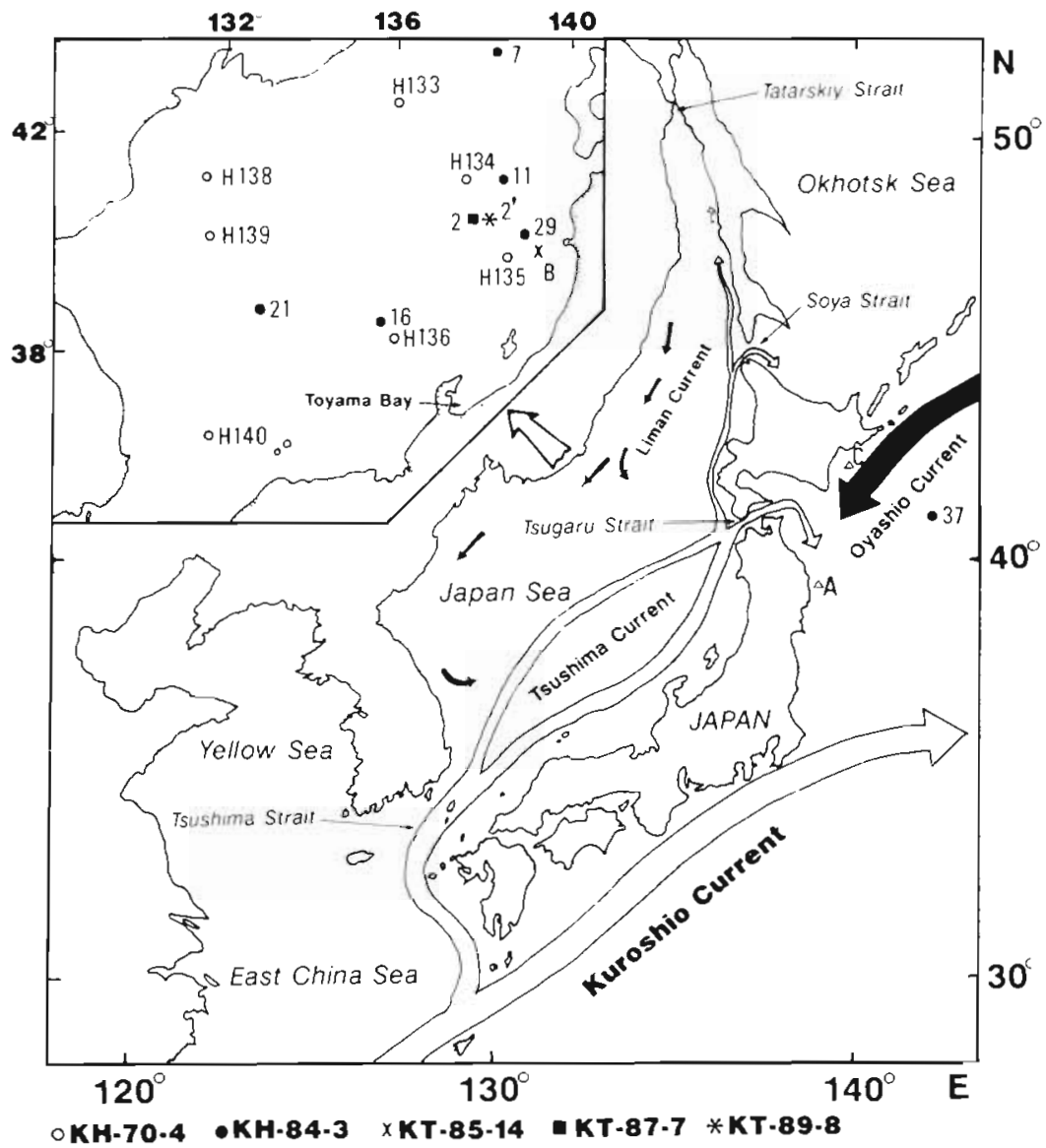

Fig. 1. Sagitta elegans. Sampling stations in the Japan Sea and present current system around the Japanese islands. [Stns A and C from Thuesen (1988)] individuals was counted and then the length of the longest hook was measured under the microscope with a micrometer (Cruise KH-84-3).

Hydrographic data from CTD casts, bathythermograph casts or Nansen bottle casts (Cruise KH-70-4) were collected at all stations.

In the laboratory, Sagitta elegans Stage III (adult), Stage II, Stage I and juveniles were thoroughly sorted from the original samples according to Thomson's (1947) criteria, and the number of individuals for each stage was recorded.

The gut contents of each individual collected during Cruises KH-84-3, KT85-14 and KT-89-8 were examined with a stereomicroscope. Consumption by Sagitta elegans of other animals in the net could have unnaturally increased the frequency of food iterns in their gut; therefore, food organisms in the mouths were not included in the data. The foodcontaining ratio (FCR; number of $S$. elegans containing food organisms in the gut/total number of $S$. elegans examined) was obtained for different layers. The cod end bucket of the MTD net consists of a cylinder $(5 \mathrm{~cm}$ diameter, $10 \mathrm{~cm}$ length) made of polyvinyl chlo-
1970 during Cruise KH-70-4, an opening-closing ORI100 net with a $1 \mathrm{~mm}$ mesh size was towed horizontally at 2 knots in 11 to 15 different strata at Stns H133, H136 \& H139. Simultaneous horizontal tows were carried out with 5 to $13 \mathrm{MTD}$ closing nets with a $0.33 \mathrm{~mm}$ mesh size in September (Cruise KH-84-3: Stns 7, 11, 16, 21 \& 29; Cruise KT-85-14: Stn B) and in June (Cruise KT-87-7: Stn 2; Cruise KT-89-8: Stn 2'). The course of the net in the water was directly recorded with a TSK Depth Distance Recorder A flowmeter was set on each net ring to measure the volume of water filtered. Sampling procedures are summarized in Table 1. Collections were preserved in $10 \%$ formalin seawater neutralized with hexamine or sodium tetraborate. Some samples collected during Cruises KH-84-3 and KT-87-7 were rinsed quickly with distilled water and then stored in the dark at $-80^{\circ} \mathrm{C}$ for carbon and nitrogen content analyses. Material for histological study of the intestinal tissue was fixed in Bouin's fluid during Cruise KH-84-3. Thereafter, the fixed tissues were embedded in paraffin, sectioned at $5 \mu \mathrm{m}$ thickness and stained with haematoxylin and eosin. The number of grasping hooks, anterior teeth and posterior teeth of 20

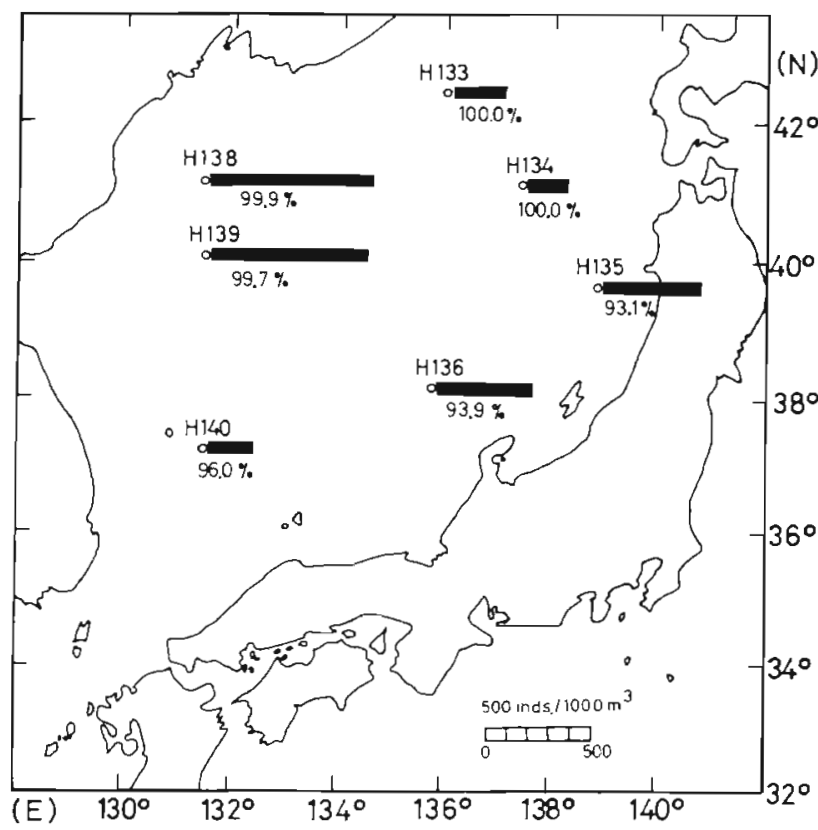

Fig. 2. Sagitta elegans. Horizontal distribution of relative abundance in samples, collected with an ORI net (0 to $1000 \mathrm{~m}$ ) in the Japan Sea, summer 1970 
ride and GG54 nylon netting bag ( $0.33 \mathrm{~mm}$ mesh size) which covers the posterior half of the cylinder. Therefore, $S$. elegans cannot survive in the cod end during sampling and the feeding in the net can be neglected.

\section{RESULTS}

\section{Distribution}

Seventeen species belonging to 3 genera were collected from the Japan Sea on our 5 cruises: Sagitta crassa, S. elegans, S. enflata, S. ferox, S. hexaptera, S. minima, S. nagae, S. neglecta, S. pacifica, S. pseudoserratodentata, $S$. regularis, $S$. robusta, $S$. decipiens, $S$. lyra, Pterosagitta draco, Krohnitta pacifica and $K$. subtilis.

The most abundant species was Sagitta elegans, comprising 93.9 to $100.0 \%$ of the individuals collected from the 0 to $1000 \mathrm{~m}$ layer (Fig. 2).

Sagitta elegans typically inhabits the upper 100 to $150 \mathrm{~m}$ in the arctic and subarctic areas of both the Atlantic and Pacific (Alvariño 1965. Terazaki \&

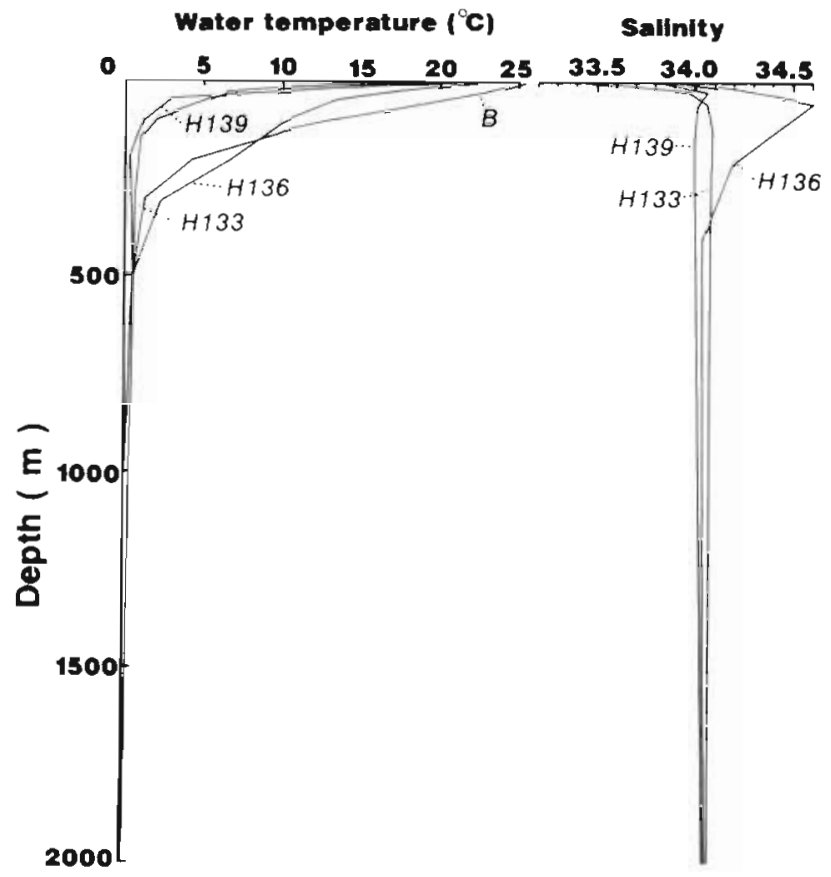

Fig. 3. Vertical profiles of water temperature and salinity at Stns H133, H136, H139 \& B

Table 1. Data on zooplankton sampling in the Japan Sea

\begin{tabular}{|c|c|c|c|c|c|}
\hline Cruise & Strn & Date & Type of net & $\begin{array}{l}\text { Towing } \\
\text { method }\end{array}$ & Sampling layer (m) \\
\hline \multirow[t]{2}{*}{$\mathrm{KH}-70-4$} & $\mathrm{H} 133$ & $2-5$ Aug 1970 & ORI-100 & Horizontal & $\begin{array}{l}\text { Surface, } 0-45,0-65,150-250,180-280 \\
260-360,550-600,570-730,850-1100 \\
870-1050,1300-1650,1600-2000 \\
3500-3850\end{array}$ \\
\hline & & 5 Aug 1970 & & Oblique & $0-950$ \\
\hline $\mathrm{KH}-70-4$ & $\mathrm{H} 135$ & 6 Aug 1970 & ORI-100 & Oblique & $0-1200$ \\
\hline \multirow[t]{2}{*}{$\mathrm{KH}-70-4$} & $\mathrm{H} 136$ & 6-9 Aug 1970 & ORI-100 & Horizontal & $\begin{array}{l}\text { Surface, } 0-50,0-75,120-165,140-180 \\
240-320,350-450,430-680,590-800 \\
1300-1620,1750-2400\end{array}$ \\
\hline & & 6 Aug 1970 & & Oblique & $0-1200$ \\
\hline $\mathrm{KH}-70-4$ & H138 & 17 Aug 1970 & ORI-100 & Oblique & $0-1100$ \\
\hline \multirow[t]{2}{*}{$\mathrm{KH}-70-4$} & H139 & 18-21 Aug 1970 & ORI-100 & Horizontal & $\begin{array}{l}\text { Surface, } 0-30,0-40,50-100,110-200 \\
150-210,160-340,180-310,390-580 \\
480-550,550-800,600-1000 \\
1000-1400,1100-1700,1600-2200\end{array}$ \\
\hline & & 20 Aug 1970 & & Oblique & $0-850$ \\
\hline $\mathrm{KH}-70-4$ & $\mathrm{H} 140$ & 22 Aug 1970 & ORI-100 & Oblique & $0-1250$ \\
\hline $\mathrm{KH}-84-3$ & 7 & 11-12 Sep 1984 & MTD & Horizontal & Surface, $200,500,700,1000$ \\
\hline KH- $84-3$ & 11 & 13-14 Sep 1984 & MTD & Horizontal & Surface, $200,500,700,1000$ \\
\hline $\mathrm{KH}-84-3$ & 16 & 17 Sep 1984 & MTD & Horizontal & Surface, $200,500,700,1000$ \\
\hline $\mathrm{KH}-84-3$ & 21 & 24 Sep 1984 & MTD & Horizontal & Surface, $200,500,700,1000$ \\
\hline $\mathrm{KH}-84-3$ & 29 & 27 Sep 1984 & MTD & Horizontal & Surface, $200,500,700,1000$ \\
\hline $\mathrm{KH}-85-14$ & $\mathrm{~B}$ & $7-8$ Sep 1985 & MTD & Horizontal & $\begin{array}{l}\text { Surface, } 10,20,30,50,70,100,200,300 \text {, } \\
400,500,700,1000\end{array}$ \\
\hline $\mathrm{KT}-87-7$ & 2 & 10 Jun 1987 & MTD & Honzontal & $\begin{array}{l}\text { Surface, } 10,25,50,100,250,500,750 \\
1000,1500\end{array}$ \\
\hline KT-89-8 & $2^{\prime}$ & 9 Jun 1989 & MTD & Horizontal & $\begin{array}{l}\text { Surface, } 25,50,100,200,300,500,750 \text {, } \\
1000,1250,1500\end{array}$ \\
\hline
\end{tabular}




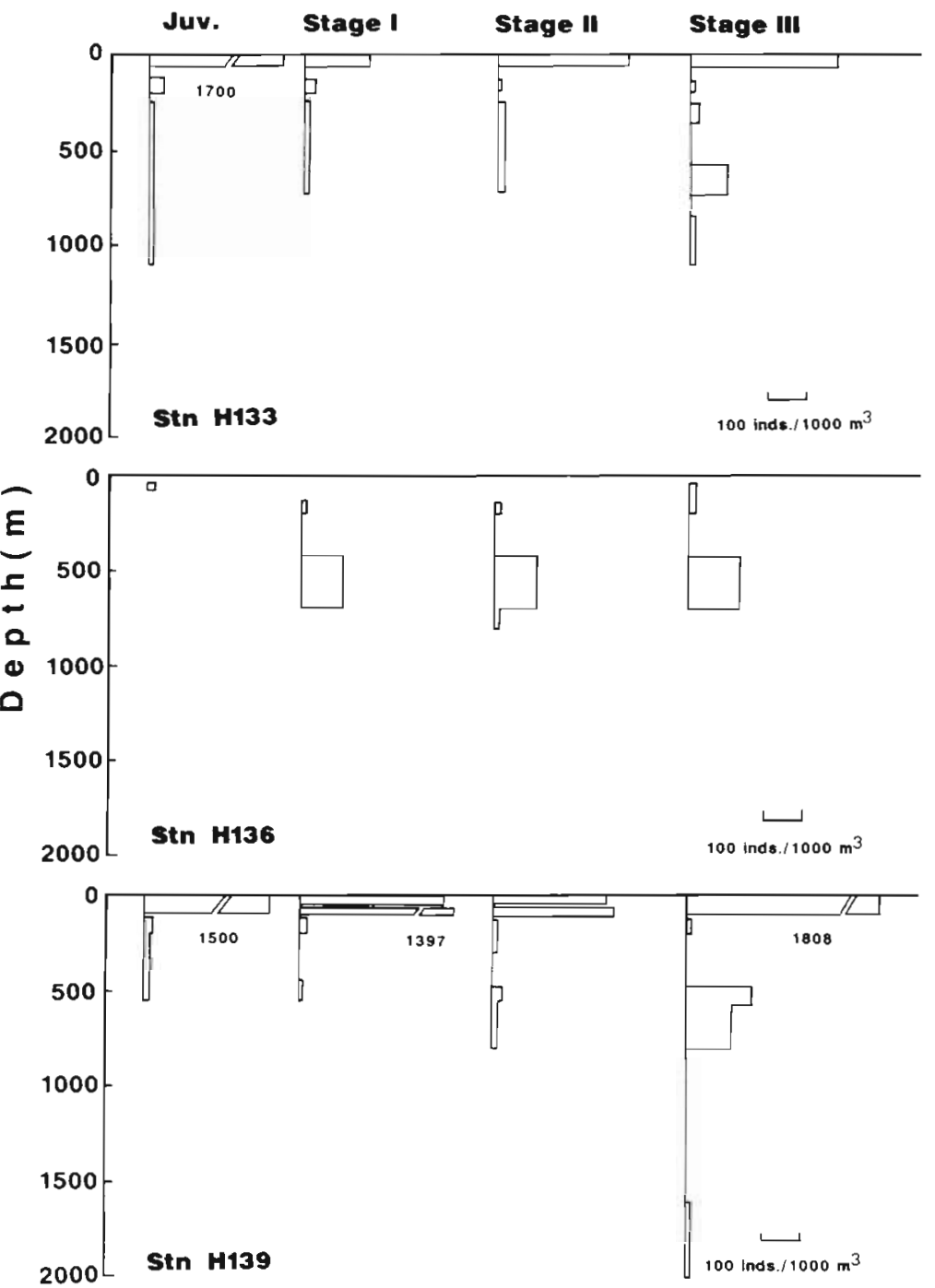

Fig. 4. Sagitta elegans. Vertical distribution of each maturity stage at Stns H133, H136 \& H139 during Cruise KH-70-4
S. hexaptera, S. decipiens, S. minima, S. nagae and Ptero-sagitta draco were distributed in the surface layer above the thermocline, and $S$. elegans was abundant below $200 \mathrm{~m}$ (Fig. 6).

The vertical distribution was slightly shallower in the daytime than at night at Stn B (Fig. 7). Clear evidence of diurnal vertical migration as described by Terazaki \& Marumo (1979) was not recognized, because our sampling stratum was too large.

\section{Food items and FCR}

A total of 1510 out of 6053 individual Sagitta elegans were found to have one or more prey organisms in their gut. The predominant prey were copepods, and the proportions of Copepoda, Chaetognatha, Ostracoda and unidentified items in the gut of $S$. elegans were 74.6, $1.7,3.4$ and $20.3 \%$, respectively (Table 2 ). Most frequent were calanoid copepods such as species of Neocalanus and Paracalanus. Scaphocalanus sp. and Aetideus sp., which also were found in $S$. elegans gut contents, are meso- and bathypelagic calanoids. There was no diel variation in the proportions of the various prey ingested.

The FCR of Sagitta elegans from the surface layer (Stns 7 \& 11) was very high $(44.7$ and $73.6 \%)$ compared with that in other strata. FCR decreased with depth and was $0 \%$ in the layer below $1000 \mathrm{~m}$
Marumo 1979, Terazaki \& Miller 1986). A distinct thermocline and salinity gradient existed in the epipelagic layer (upper $200 \mathrm{~m}$ ) at all stations (Fig. 3). The surface layer at Stns H136, 11, 16, 29 \& B was influenced considerably by the warm Tsushima Current. Water colder than $2{ }^{\circ} \mathrm{C}$ was present at depths below $200 \mathrm{~m}$. In the Japan Sea, $S$. elegans was distributed widely between 50 and $2000 \mathrm{~m}$. The layer of maximum abundance differed with sampling area. Juveniles had different distributions from maturing and adult individuals (Fig. 4). They were abundant from 50 to $500 \mathrm{~m}$ in the northern Japan Sea (Stns H133, H139, 7 \& 11) and from 200 to $700 \mathrm{~m}$ in the southern Japan Sea (Stns H136, 21 \& 29) where the warm Tsushima Current was rather shallow (Figs. \& \& 5). High concentrations of adults (more than 100 ind. per $1000 \mathrm{~m}^{3}$ ) were found in the layer below $500 \mathrm{~m}$. S. enflata, S. robusta, S. pacifica,
Table 2. Sagitta elegans. Food organisms found in the gut

\begin{tabular}{|c|c|}
\hline Food organisms & $\%$ \\
\hline \multicolumn{2}{|l|}{ Copepoda } \\
\hline Neocalanus spp. & 5.1 \\
\hline Paracalanus parvus & 1.7 \\
\hline Paracalanus sp. & 3.4 \\
\hline Acrocalanus gracilis & 1.7 \\
\hline Scaphocalanus sp. & 1.7 \\
\hline Oithonasp. & 1.7 \\
\hline Undinopsis sp. & 1.7 \\
\hline Aetideus sp. & 1.7 \\
\hline Unidentified calanoids & 50.8 \\
\hline Unidentified copepods & 5.1 \\
\hline \multicolumn{2}{|l|}{ Chaetognatha } \\
\hline Sagitta elegans & 1.7 \\
\hline \multicolumn{2}{|l|}{ Ostracoda } \\
\hline Conchoecia pseudodiscophora & 3.4 \\
\hline Unidentified organisms & 20.3 \\
\hline
\end{tabular}




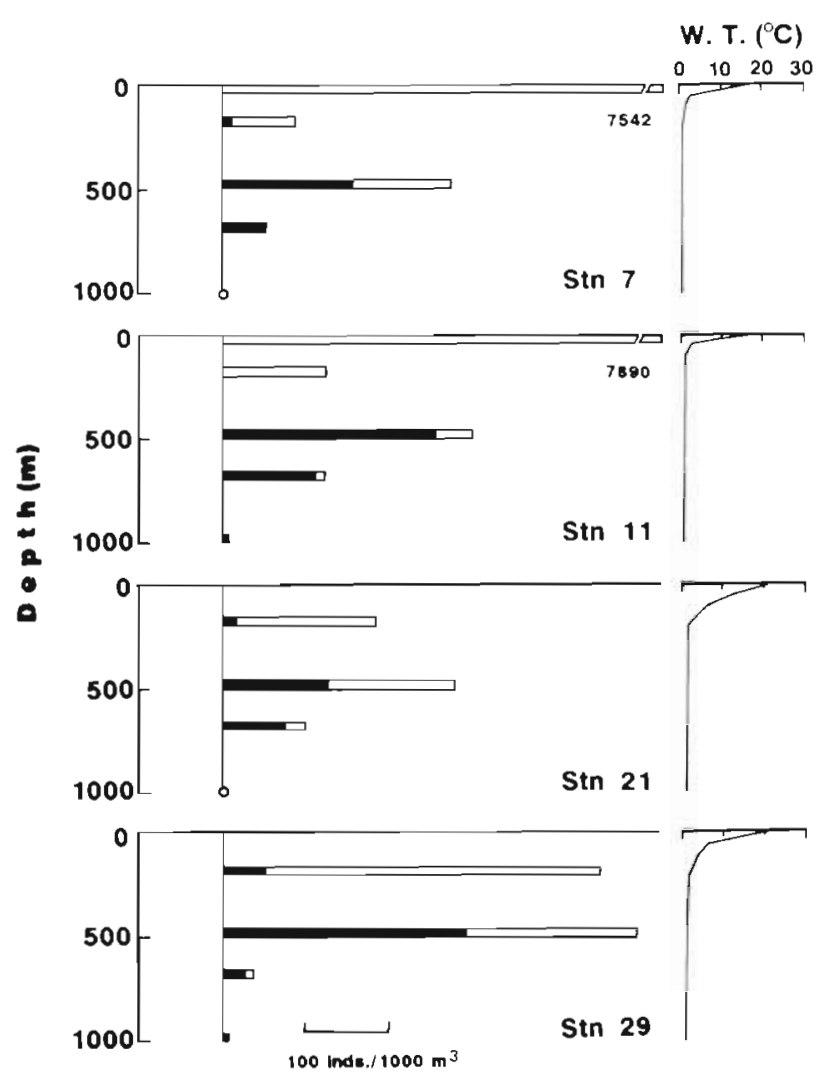

Fig. 5. Sagitta elegans. Vertical distribution, with water temperature profiles, at Stns 7, 11, $21 \& 29$ during Cruise KH-843. Shaded area represents the proportion of Stage III individuals

(Table 3). There were no marked differences in FCR between day and night except at $200 \mathrm{~m}$ depth at Stn B (Table 4). The nighttime FCR in the layer between 200 and $500 \mathrm{~m}$ at Stn $\mathrm{H} 133$ was $14.0 \%$ (Table 5).

Bodies of Sagitta elegans (almost Stages II and III)

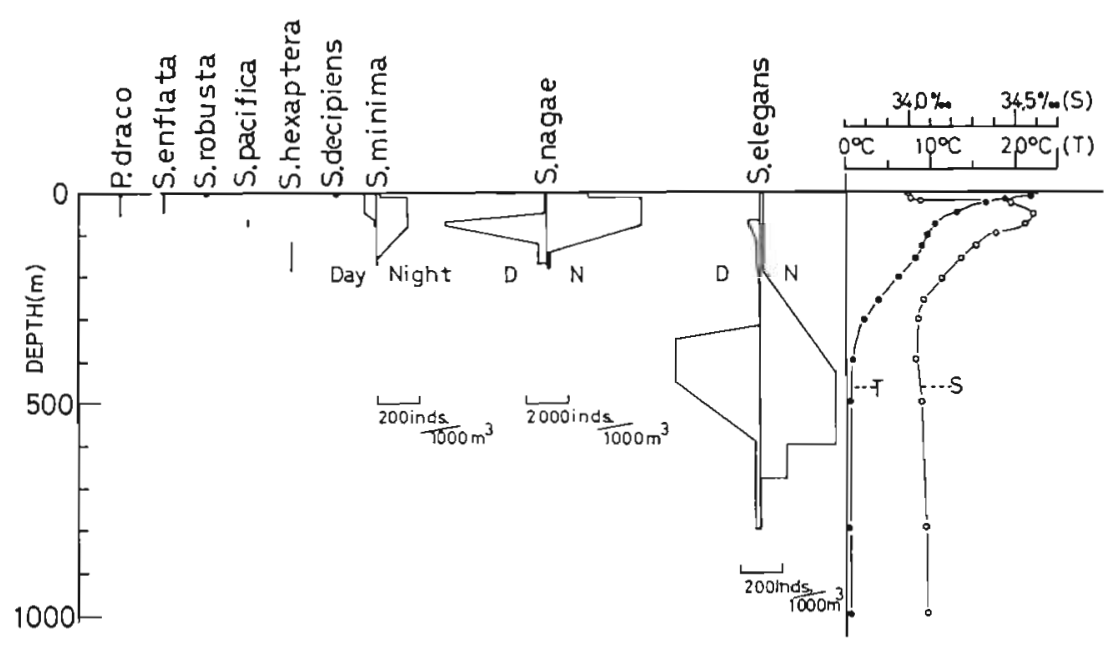

Fig. 6. Vertical distribution of pelagic chaetognaths, with water temperature profiles, at Stn H136

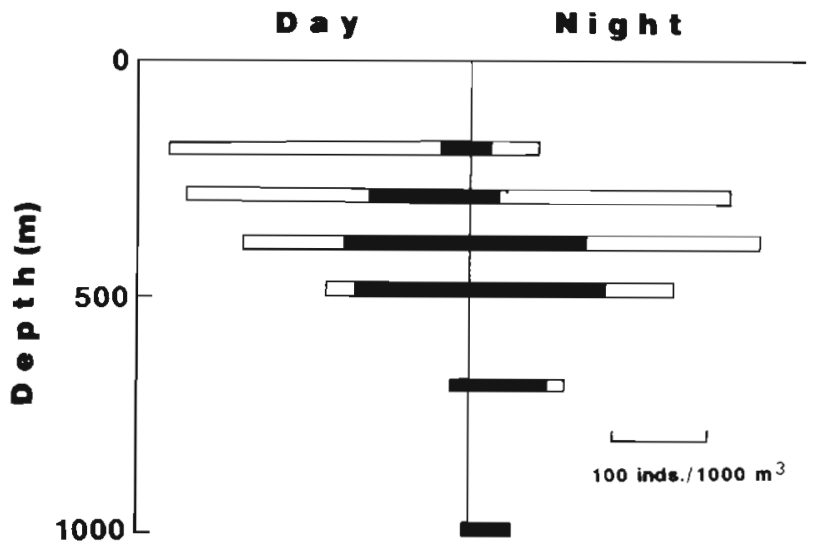

Fig. 7. Sagitta elegans. Vertical distribution at Stn B during Cruise KT-85-14. Shaded area represents the proportion of Stage III individuals

collected from the meso- and bathypelagic layer below $200 \mathrm{~m}$ contained large numbers of yellow oil droplets (Table 6).

\section{Grasping hooks and teeth}

Grasping hooks are used in seizing prey, and the much shorter anterior and posterior teeth curving around the front of the head also assist in capturing prey.

The number of hooks and teeth of Sagitta elegans increases as individuals mature. The numbers of hooks, anterior teeth and posterior teeth of $S$. elegans collected from the Japan Sea (Stn 11) were, respectively, 8 to 11 pairs, 4 to 8 pairs, and 10 to 24 pairs. On the other hand, the numbers of hooks and anterior and posterior teeth of $S$. elegans inhabiting the epipelagic layer of the Pacific side of the sampling area (Stn 37) were 8 to 10 , 3 to 7 , and 6 to 10 , respectively. Japan Sea $S$. elegans had large hooks compared with Pacific specimens (Fig. 8). A relation was established between the maximum hook length $(Y)$ and body length $(X)$. Regression equations in the Japan Sea and the Pacific were, respectively, $\quad Y=0.042 X-0.117$ $\left(\mathrm{R}^{2}=0.992\right)$ and $Y=0.038 X-0.151$ $\left(R^{2}=0.994\right)$. The 2 regression lines were significantly different, and the $F$-value obtained in the analysis of covariance was 59.62. The pvalue with respect to the $F$ distribution (with $\mathrm{df}=21,2$ ) was much less than 0.01 . 
Table 3. Sagitta elegans. Food-containing ratio (\%) at Stns 7 , $11,21 \& 29$ during Cruise $\mathrm{KH}-84-3$, - : no sampling

\begin{tabular}{|ccccc|}
\hline $\begin{array}{c}\text { Sampling depth } \\
(\mathrm{m})\end{array}$ & 7 & 11 & 21 & 29 \\
\hline 0 & 44.7 & 73.6 & & \\
200 & 45.8 & 0 & 0 & 3.0 \\
500 & 17.5 & 3.3 & 0 & 2.0 \\
700 & 12.9 & 3.6 & 5.7 & 0 \\
1000 & - & 0 & - & 0 \\
\hline
\end{tabular}

Table 4. Sagitta elegans. Food-containing ratio (\%) at Stn B during Cruise KT-85-14

\begin{tabular}{|ccl|}
$\begin{array}{c}\text { Sampling depth } \\
(\mathrm{m})\end{array}$ & Day & Night \\
\hline 200 & 10.8 & 0 \\
300 & 2.8 & 2.0 \\
400 & 1.0 & 3.2 \\
500 & 5.8 & 1.0 \\
700 & 0 & 2.0 \\
1000 & 0 & 0 \\
\hline
\end{tabular}

Table 5. Sagitta elegans. Food-containing ratio (\%) at Stn $\mathrm{H} 133$ during Cruise $\mathrm{KH}-70-4$

\begin{tabular}{|ccc|}
\hline $\begin{array}{c}\text { Sampling layer } \\
(\mathrm{m})\end{array}$ & Day & Night \\
\hline $0-200$ & & - \\
$200-500$ & 6.6 & 5.7 \\
$500-800$ & 8.7 & 14.0 \\
$800-1100$ & 7.5 & 6.9 \\
\hline
\end{tabular}

Table 6. Sagitta elegans. Percentage of individuals with bodies containing oil droplets at Stns 7, 11, 21 \& 29 during Cruise $\mathrm{KH}-84-3$. -: no sampling

\begin{tabular}{|ccccc|}
\hline $\begin{array}{c}\text { Sampling depth } \\
(\mathrm{m})\end{array}$ & 7 & 11 & 21 & 29 \\
\hline 0 & 0 & 0 & & \\
200 & 0 & 0 & 0 & 3.0 \\
500 & 2.7 & 10.2 & 34.0 & 9.1 \\
700 & 0 & 1.4 & 2.9 & 24.3 \\
1000 & - & 0 & - & 0 \\
\hline
\end{tabular}

\section{Intestinal tissue}

After capture, the prey is pushed into the mouth, in which it is lubricated by pharyngeal secretions, and then passed to the posterior intestine. Here the food is rotated and moved back and forth until it is broken down. The intestine is lined with secretory and absorptive cells (Grey 1930). Generally, the body width of

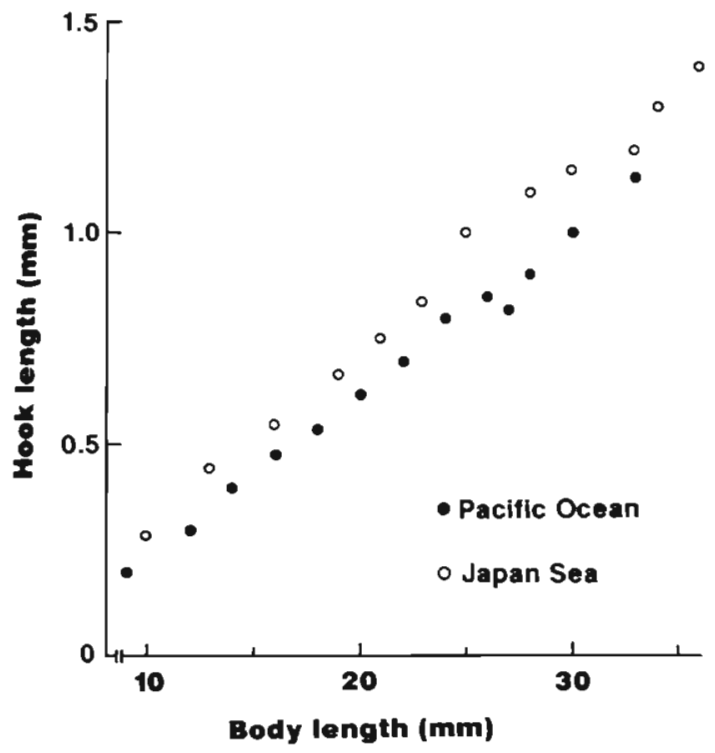

Fig. 8. Sagitta elegans. Relationship between largest hook length and body length of individuals collected from the Japan Sea and Pacific Ocean

Sagitta elegans in the Japan Sea is greater than that in the Pacific. S. elegans, collected from the layer between 200 and $700 \mathrm{~m}$ at Stn 11 in the Japan Sea, had well-developed intestinal tissue (100 to $300 \mu \mathrm{m}$ thick), but it was very thin (less than $100 \mu \mathrm{m}$ ) in S. elegans inhabiting the epipelagic layer at Stn 37 in the Pacific (Fig. 9). Small oil droplets were recognized in the intestinal tissue, as mentioned above.

\section{Chemical composition}

The regression between body carbon and body length of Sagitta elegans collected from the meso- and bathypelagic layer at Stn 7 was higher than that for individuals from the epipelagic layer of the Pacific (Fig. 10) and the regression equations of body length $(\mathrm{mm} ; X)$ vs carbon $(\mathrm{mg} ; Y)$ in the Japan Sea and the Pacific were $Y=0.057 X^{1.161}\left(\mathrm{R}^{2}=0.693\right)$ and $Y=$ $0.002 X^{2.093}\left(R^{2}=0.778\right)$, respectively. However, the 2 regression lines were not significantly different, as the $F$-value obtained in the analysis of covariance was 1.854. Mean carbon/nitrogen ratios of $S$. elegans in the Japan Sea and Pacific were $4.7(\mathrm{SD}=0.1)$ and $3.5(\mathrm{SD}$ $=0.2$ ), respectively.

\section{DISCUSSION}

Much information has been presented on the vertical distribution of Sagitta elegans in the northern North 

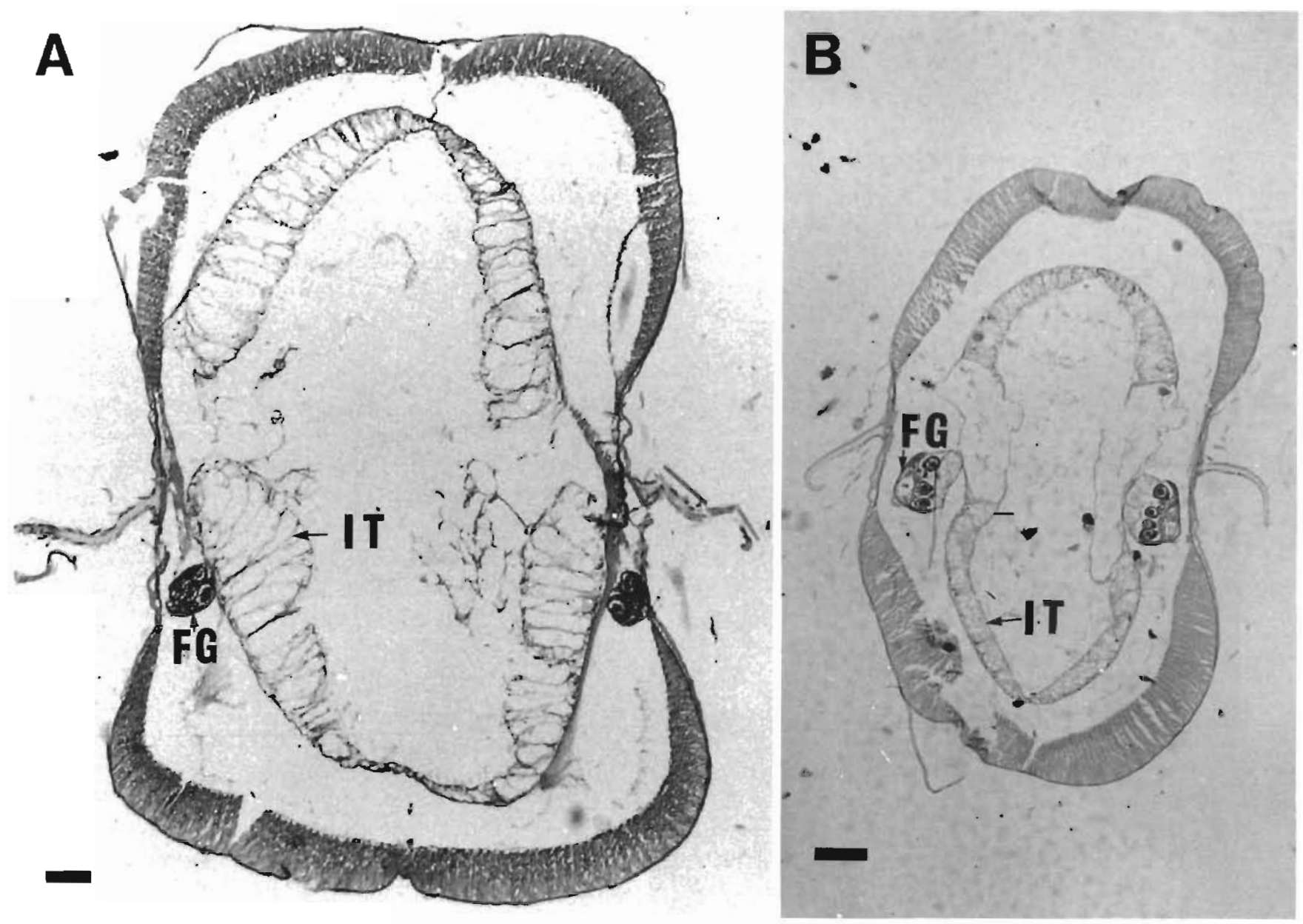

Fig. 9. Sagitta elegans. Transverse section of part of trunk showing intestinal tissue (IT) and female gonad (FG) of individuals collected from the Japan Sea ( $A ; 35 \mathrm{~mm}$ body length) and the Pacific Ocean (B; $33 \mathrm{~mm}$ ). Scale bars $=100 \mu \mathrm{m}$

Pacific Ocean (Tchindonova 1955, Bieri 1959, Alvariño 1965, Kotori 1972, King 1979, Sullivan 1980, Terazaki \& Miller 1986) and $S$. elegans is a typical epipelagic

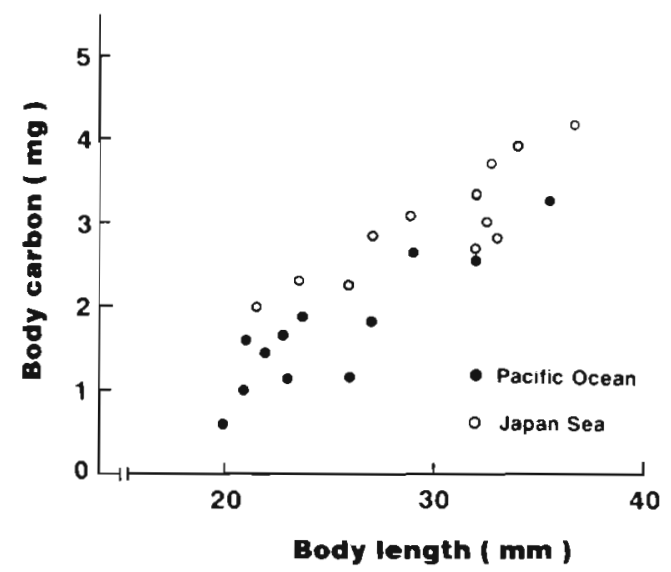

Fig. 10. Sagitta elegans. Relationship between body carbon and body length of individuals collected from the Japan Sea and Pacific Ocean species in the Subarctic Water. But during our cruises, many individuals were collected from water of the Japan Sea proper, below a depth of $200 \mathrm{~m}$. According to Terazaki \& Marumo (1979), S. elegans inhabiting the Japan Sea undergo larger-scale diurnal vertical migration compared with the Pacific populations. The distance of vertical migration at the station $\left(42^{\circ} 30^{\prime} \mathrm{N}\right.$, $138^{\circ} 34^{\prime} \mathrm{E}$ ) in the northern Japan Sea was 10 to $20 \mathrm{~m}$ in juveniles, 20 to $30 \mathrm{~m}$ in Stage I, 90 to $170 \mathrm{~m}$ in Stage II and 150 to $200 \mathrm{~m}$ in Stage III (adult). Therefore, it is not possible that large individuals distributed in the mesoand bathypelagic layer below $500 \mathrm{~m}$ reach the epipelagic layer by upward migration. Apart from $S$, elegans, 3 species of Polychaeta - Polycirrus medusa, Chaetozone setosa and Anobothrus gracilis, which are distributed in the epipelagic layer of the Pacific - were collected from water of the Japan Sea proper (Uschakov 1955). Nishimura (1968) reported that many fishes which are epipelagic in the Pacific Ocean were distributed in deep waters of the Japan Sea. A large herbivorous copepod, Neocalanus cristatus (Stage V), 
has been reported to occur as deep as $1600 \mathrm{~m}$ (Miller et al. 1984) and $2000 \mathrm{~m}$ (Sekiguchi 1975) in the northern North Pacific, whereas the maximum sampling depth of $N$. cristatus in the Japan Sea was $3850 \mathrm{~m}$ (Terazaki \& Wada 1988).

Eukrohnia hamata and Sagitta scrippsae are abundant species in the epipelagic or upper mesopelagic (200 to $500 \mathrm{~m}$ ) layer of the Pacific near the Tsugaru and Soya straits (Kitou 1974, Kotori 1976. Terazaki 1992). There is no previous report of their collection from the Japan Sea, and we could not find these species during our 5 cruises. Recently, many physical oceanographers have discussed the current system in the Tsugaru and Soya straits. The effect of the Tsushima Current was very strong in both straits. However, no counter-current from the Pacific into the Japan Sea was detected (Aota et al. 1988, Shikama unpubl.). The absence of $E$. hamata and S. scrippsae from the Japan Sea strongly supports the results of investigations by physical oceanographers. Water exchange through the Tatarskiy Strait, which is only $15 \mathrm{~m}$ at its deepest point and freezes except in summer, is very infrequent (Tabata et al. 1980). Therefore, the origin of $S$. elegans living in the Japan Sea is an interesting problem.

Japanese geologists have studied the paleoenvironmental changes in the Japan Sea during the last 85000 yr from the sedimentary record in a piston core from the Oki Ridge. According to their reports (Kato 1979, Masuzawa \& Kitano 1983, 1984, Oba et al. 1991), 5 distinct changes are revealed. Between 85000 and 27000 yr ago, the warm Tsushima Current did not flow into the Japan Sea, and cold surface water conditions prevailed. Conditions at the sea floor fluctuated between dysaerobic and weakly oxic. Between 27000 and 20000 yr ago, freshwater input to the Japan Sea, probably from the Huang Ho River in China, stratified the water column, and severely anoxic conditions eliminated most benthic fauna. Between 20000 and 10000 yr ago, the cold Oyashio Current flowed into the Japan Sea through the Tsugaru Strait, re-establishing deepwater ventilation. Between 10000 and 8000 yr ago the foraminiferan compensation level gradually rose to a depth less than $1000 \mathrm{~m}$, and bottom conditions changed from dysaerobic to oxic. At $10000 \mathrm{yr}$ ago, the warm Tsushima Current began flowing into the Japan Sea through the Tsushima Strait, to establish the modern oceanographic regime which has existed over the last 8000 yr. If this scheme is valid, it becomes considerably easier to understand the invasion of Sagitta elegans from the North Pacific Ocean, and the significance of vacant niches in the deep water between 20000 and 10000 yr ago.

Recently, an electrophoretic isozyme study was undertaken to compare the genetic composition of
Sagitta elegans in the Japan Sea with that in the Pacific (Thuesen 1988). S. elegans was found to display very low levels of genetic variability. On the basis of allele frequencies at 2 enzyme loci it is possible that $S$. elegans population samples collected in the Japan Sea were reproductively isolated from those at Stns A \& C (see Fig. 1) in the Pacific. However a preliminary study of genetic distance suggests the range of variation is intraspecific. Ten thousand years is not long enough for geographic speciation in the case of the Chaetognatha.

Morphological differences are recognized in the grasping hooks, teeth and intestinal tissue between the Japan Sea and Pacific populations. The Japan Sea Sagitta elegans has many large hooks and teeth, like meso- and bathypelagic species (Terazaki 1993a), and their intestinal tissue was thick compared with the Pacific $S$. elegans. The high $\mathrm{C} / \mathrm{N}$ ratio of $S$. elegans in the Japan Sea might be caused by body lipids, since many oil droplets were contained in the intestinal tissue.

In the Pacific Ocean, Sagitta elegans inhabits the epipelagic layers, Eukrohnia hamata the epipelagic and upper mesopelagic layers, E. bathypelagica the mesopelagic layer (200 to $1000 \mathrm{~m}$ ), S. macrocephala the lower mesopelagic and bathypelagic layers (500 to $2000 \mathrm{~m}$ ), and $E$. fowleri the layer below $1000 \mathrm{~m}$ (Alvariño 1965, Terazaki et al. 1985, Terazaki \& Miller 1986, Terazaki 1992). The vertical dispersal of $S$. elegans in the Japan Sea is facilitated by the absence of competitors such as E. hamata, E. bathypelagica, $E$. fowleri and S. macrocephala. According to Sullivan (1980), S. elegans preyed on larger copepods than did Eukrohnia hamata at a station in the subarctic Pacific. Main food organisms of $S$. elegans were Neocalanus cristatus, N. plumchrus, Metridia pacifica and Oithona similis, whereas E. hamata consumed Oncaea sp. On the other hand, in the Japan Sea S. elegans consumed copepods of a wide range of sizes, mainly calanoids.

FCR decreased with depth and was very low in the mesopelagic layer despite the large biomass of copepods. The FCR of juvenile, Stage I, II, III and IV individuals of meso- and bathypelagic chaetognaths (Sagitta zetesios) inhabiting Sagami Bay, central Japan, were 15.5, 20.7, 13.2, 1.5 and $3.2 \%$, respectively. Young $S$. zetesios had a high FCR compared with maturing and adult individuals (Terazaki \& Marumo 1982). The same phenomenon was recognized in the Japan Sea, but the gut of $S$ elegans collected from the layer below $1000 \mathrm{~m}$ was always empty. It may be suggested that the low temperature (below $1{ }^{\circ} \mathrm{C}$ ) of water in the Japan Sea proper controls the feeding activity of $S$, elegans. However, maturing and adult animals have developed intestinal tissue contain- 
ing lipid, like meso- and bathypelagic species, allowing them to endure starvation.

Reproduction of Sagitta elegans was reported in Toyama Bay, southern Japan Sea, where a distinct thermocline existed in the epipelagic layer due to overlayering of the Tsushima Current. S. elegans had 2 spawning periods during the year, separated by distinct gaps in both presence of mature individuals and appearance of new juveniles. Generation lengths were 10 to 12 mo (Terazaki 1993b). Therefore, S. elegans living in water of the Japan Sea proper are able to adapt to maintain their population in an environment which is unfavourable compared with the Pacific side. Deepsea adaptation since their invasion from the Pacific Ocean has enabled the dispersal of their niches into various waters of the Japan Sea.

Acknowledgements. The author expresses his gratitude to Prof. C. B. Miller of the College of Oceanography, Oregon State University, and Dr Q. Bone of the Marine Biological Association, Plymouth, UK, for their constructive comments on the manuscript. My warmest thanks to Dr S. Nishida, Ocean Research Institute, University of Tokyo, for his kind identification of copepod species, Dr H. Kishino, the same institution, for helping with statistical analysis, and Dr T. Otake and Mrs M. Wada for their technical assistance. Thanks are also due to officers and crews of the RV 'Hakuho Maru' and 'Tansei Maru' of the Ocean Research Institute, University of Tokyo, for their cooperation during the cruises.

\section{LITERATURE CITED}

Alvariño, A. (1965). Chaetognaths. Oceanogr. mar. Biol. A. Rev. 3: 115-194

Aota, M., Ishikawa, M., Yamada, T. (1988). Dynamics of flow in the Soya Strait. Low Temp. Sci. (Ser. A) 47: 147-160

Bieri, R. (1959). The distribution of the planktonic Chaetognatha in the Pacific and their relationship to the water masses. Limnol. Oceanogr. 4: 1-28

Grey, B. B. (1930). Chaetognatha from the Society Island. Proc. R. Soc. Queensland 42: 62-67

Kato, M. (1979). Age assigned to dredged siltstone samples and piston core samples. Cruise Rep. Geol. Surv. Japan 13: $70-72$

King, K. R. (1979). The life history and vertical distribution of the chaetognath Sagitta elegans in Dabob Bay, Washington. J. Plankton Res. 1: 153-167

Kitou, M. (1974). Chaetognatha. In: Marumo, R. (ed.) Marine plankton. Tokyo Univ. Press, Tokyo, p. 65-85

Kotori, M. (1972). Vertical distribution of chaetognaths in the northern North Pacific Ocean and Bering Sea. In: Takenouti, A. Y. (ed.) Biological oceanography of the northern North Pacific Ocean. Idemitsu Shoten, Tokyo, p. 291-308

Kotori, M. (1976). The biology of Chaetognatha in the Bering Sea and the northern North Pacific Ocean, with emphasis on Sagitta elegans. Mem. Fac. Fish. Hokkaido Univ. 23: 95-183
Masuzawa, T., Kitano, Y (1983). Sulfate reduction and sulfide deposition in deep-sea sediments from the south-western Japan Sea. J. oceanogr. Soc. Japan 39: $251-258$

Masuzawa, T, Kitano, $\mathrm{Y}$ (1984). Appearance of $\mathrm{H}_{2} \mathrm{~S}$-bearing bottom waters during the last glacial period in the Japan Sea. Geochem. J. 18: 167-172

Miller, C. B., Frost, B. W., Batchelder, H. P., Clemons, M. J., Conway, R. E. (1984). Life history of large, grazing copepods in a subarctic ocean gyre: Neocalanus cristatus, and Euclanus bungii in the Northeast Pacific. Prog. Oceanogr. 13: $201-243$

Motoda, S. (1971). Devices of simple plankton apparatus. V. Bull. Fac. Fish. Hokkaido Univ. 22: 101-106

Nishimura, S. (1965). The zoogeographical aspect of the Japan Sea, Part. II. Publs Seto mar. biol. Lab. 13: 81-101

Nishimura, S. (1968). The zoogeographical aspect of the Japan Sea, Part IV. Publs Seto mar. biol. Lab. 15: $329-352$

Oba, T., Kato, M., Kitazato, H., Koizumi, I., Omura, A., Sakai, T., Takayama, T. (1991). Paleoenvironmental changes in the Japan Sea during the last 85,000 years. Paleoceanography 6: 499-518

Omori, M. (1965). A $160-\mathrm{cm}$ opening-closing plankton net. I. Description of the gear. J. oceanogr. Soc. Japan 21: $212-220$

Sekiguchi, H. (1975). Seasonal and ontogenetic vertical migrations of some common copepods in the northern region of the North Pacific. Bull. Fac. Fish. Mie Univ. 2: $29-38$

Sullivan, B. K. (1980). In situ feeding behaviour of Sagitta elegans and Eukrohnia hamata (Chaetognatha) in relation to the vertical distribution and abundance of prey at ocean station P. Limnol. Oceanogr. 25: 317-326

Tabata, T, Nohguchi, Y., Saito, T. (1980). Observed sea ice thickness in the northern Okhotsk Sea. Low Temp. Sci. (Ser. A) 39: 153-158

Tchindonova, J. G. (1955). Chaetognatha of the KurileKamchatka Trench. Tr. Inst. Okeanol. Akad. Nauk SSSR 12: $298-310$

Terazaki, M. (1992). Horizontal and vertical distribution of chaetognaths in a Kuroshio warm-core ring. Deep Sea Res. 39 (Suppl. 1): S231-S245

Terazaki, M. (1993a). Grasping hooks and teeth of carnivorous zooplankton, chaetognaths. Pacif. Sci. (in press)

Terazaki, M. (1993b). Seasonal variation and life history of a pelagic chaetognath, Sagitta elegans Verrill in Toyama Bay, southern Japan Sea. J. Plankton Res. (in press)

Terazaki, M., Kitagawa, D., Yamashita, Y (1985). Vertical distribution and migration of pelagic chaetognaths in the vicinity of Otsuchi Bay in the spring season. Otsuchi mar. Res. Cent. Rep. 11: 1-7

Terazaki, M., Marumo, R. (1979). Diurnal vertical migration of Sagitta elegans Verrill in the western North Pacific Ocean. Bull. Plankton Soc. Japan 26: 11-17

Terazaki, M., Marumo, R. (1982). Feeding habits of meso- and bathypelagic chaetognatha, Sagitta zetesios Fowler. Oceanol. Acta 5: 461-464

Terazaki, M., Miller, C. B. (1986). Life history and vertical distribution of pelagic chaetognaths at ocean station P in the subarctic Pacific. Deep Sea Res. 33: 323-337

Terazaki, M., Wada, M. (1988). Occurrence of large numbers of carcasses of the large, grazing copepod Calanus cristatus from the Japan Sea. Mar. Biol. 97: 177-183

Thomson, J. M. (1947). The Chaetognatha of south-eastern Australia. Bull. Coun. scient. ind. Res. 222: 4-43 
Thuesen, E. V. (1988). Biochemical genetic investigations of chaetognaths. Master's thesis. Faculty of Agriculture, University of Tokyo

Uschakov, P. V. (1955). Polychaetous annelids of the far east-

This article was presented by K. Furuya, Tsu, Japan ern seas of the USSR. Ed. ZIN Acad. Sci. USSR, Moscow \& Leningrad

Zenkevitch, L. A. (1963). Biology of the seas of the USSR. Allen \& Unwin, London

Manuscript first received: October 27, 1992

Revised version accepted: March 31, 1993 